\title{
Challenging National Narratives: On the Origins of Sweet Potato in China as Global Commodity During the Early Modern Period
}

\author{
Manuel Perez Garcia
}

This research has been sponsored and financially supported by the GECEM ('Global Encounters between China and Europe: Trade Networks, Consumption and Cultural Exchanges in Macau and Marseille, 1680-1840') project hosted by the Pablo de Olavide University, UPO (Seville, Spain). The GECEM project is funded by the ERC (European Research Council)-Starting Grant, under the European Union's Horizon 2020 Research and Innovation Programme, ref. 679371, http:// www.gecem.eu. The P.I. (Principal Investigator) is Professor Manuel Perez Garcia (Distinguished Researcher at UPO). I am grateful to comments and suggestions on the earliest version of this chapter by Professor Harriet Zurndorfer (Leiden University), who are outstanding specialists in the field of East Asian and Chinese Studies. Any mistakes and errors in this chapter are under author's responsibility.

M. Perez Garcia $(\square)$

Shanghai Jiao Tong University, Shanghai, China

(C) The Author(s) 2018

M. Perez Garcia and L. de Sousa (eds.), Global History and New

Polycentric Approaches, Palgrave Studies in Comparative Global History, https://doi.org/10.1007/978-981-10-4053-5_4 


\section{INTRODUCTION}

The introduction of American cereal crops is probably one of the most important events in China's agricultural history, having a great effect on the agriculture production, national life (He Bingdi 1979), the transformation of consumer behaviour and, to some extent, the nationalization of consumption. The sweet potato (Ipomoea Batatas L.), in Chinese gānshŭ 甘薯, is a staple food crop for ancient Chinese society. Today it still plays an important role in Chinese daily life, as well as guaranteeing national food security. Sweet potato and other crops from American origin such as corn (yùmǐ 玉米), potato (shǔ 薯), chili (làjiāo 辣椒) and dragon fruit or pitalla (huǒlóng guǒ 火龙果) were introduced through the Manila-Acapulco galleons in the last phase of Ming dynasty, transforming the Chinese economy, improving cultivation techniques and forming an important part of the peasant-farmer's basket of crops (Marks 1998). The analysis and impact on the Chinese economy of such cropsin this chapter the focus is on the case of sweet potato-might shed light to the debate of the great divergence and the question posed by Pomeranz (2000) and Bin Wong (1997) on what were the forces that prevent China to escape from Malthusian constraints. As we can see in the data provided in this chapter, the rise in consumption of crops such as sweet potato contributed to the rapid increase of the Chinese population. This is an important factor in comprehending the economic transformation of China during the last period of the Ming dynasty, as well as the Qing dynasty.

In addition, another important dimension of the analysis is the nationalization of these American crops that entered China. The current debate in Chinese academia as to whether sweet potato is indigenous to China or from American origin is notable proof of such a process of nationalization that Chinese historiography during recent years has attempted to reinforce within a solid national narrative. 'There is nothing we don't have that we need from you'-this statement was made by Emperor Qianglong to Lord Maccartney during his mission to China in 17921793, whose aim was to show to Western powers, mainly England, the self-sufficiency of the Chinese economy (Waley-Cohen 1993; Berg 2006).

The powerful meaning of such an affirmation still echoes nowadays in Chinese academia within the re-affirmation of the long-standing history and cultural roots of Chinese civilization, which attempts to reaffirm its uniqueness. For this reason, the main aim of this chapter is to analyse the origins, channels of diffusion, distribution and impact of the 
sweet potato in Chinese economy by making an overview of Chinese historiography to observe how this topic has been analysed. Thus, it is important to comprehend how this subject has evolved since the early days of the foundation of the People's Republic of China (PRC) and whether the studies on sweet potato in the field of economic history has been framed as a new national narrative. A survey has been made in the main academic database of China, CNKI (China National Knowledge Infrastructure $)^{1}$ and Chaoxing, ${ }^{2}$ from 1958 to 2015. It is acknowledged that the search is as comprehensive as the material databases provided and inevitably the author's own judgement is reflected in this literature review due to the current constraints in terms of accessing original Chinese sources, and the obvious limits of the research on the topic due to political pressures in China during the second half of the twentieth century until today.

The analysis of the introduction of global commodities of American origin in China-in this case the origins and distribution of sweet potato-represents a valuable example of how global history is penetrating into Chinese academic circles and how it is implemented conceptually and methodologically. Such an example might illustrate the real challenges of global history mainly in an academic context very much influenced by political and ideological constraints, in which the role of history is certainly to foster the new patriotic and national effervescence and to maintain the unification of the diverse population of China (which comprises around 55 ethnic minorities). The major aim is therefore to present the uniqueness of Chinese civilization and history. This is the main objective of the current neo-Confucian policies, from which the field of social sciences and humanities is not absent (Huang and Gove 2012; Tu 1998). The form of writing history-we might say the patriotic historicism-reflects such political and ideological practices. An apparently irrelevant topic - for example, the study of the introduction of new agricultural crops of American origin in China, such as sweet potato, chili or potato-is not as trivial as we might believe. Certainly, as will be seen in the following pages, a process of 'nationalization of consumption' or 'nationalizing global history' can be demonstrated in the way in which an important group of Chinese scholars believe that sweet potato is indigenous to China.

Therefore, Chinese academic circles, the traditional Marxist school of China has a strong influence in presenting history to the general and non-academic audience and the public consciousness (Liu Shuang 2002; Qian Chengdan 2001). This makes difficult to put global history 
in practice (Northrop 2012) since the main challenge and obstacle is to overcome such nationalistic and patriotic myopias (Yu Pei 2006; Wu Xiaoqun 2005). For real practitioners of global history, the confrontation of such ideological and political apparatus entails some methodological problems, since the lack of infrastructure and an international academic environment prevents the creation of a core curriculum, courses, seminars and workshops by which global history could be deeply discussed methodologically and theoretically (An Changchun 1993; Liang ZhanJun 2006; Liu Beicheng 2000). A pedagogical turn is more than necessary-in other words, making a public pedagogical function to bring about an academic consciousness to institutionalize global history by which internationalization, mobility and diversity should be firmly rooted at the department, faculty and university levels.

\section{Towards a New National Narrative: The Evolution on Studies of Sweet Potato in Chinese Historiography}

For the overview of the Chinese research on the introduction and distribution of sweet potato in China, the Chaoxing and CNKI databases have been employed, searching keywords such as fānnshǔ (番薯), gānshŭ (甘 薯), hóngshǔ (红薯), chuán rù (传入), which means introduction of sweet potato, to analyse the early origins of sweet potato. The research has been completed and limited to the scarce articles and journals related to the topic. The total number of journal articles is 168 (see Fig. 1). All retrieved articles have been examined to find those that focused particularly on the introduction and distribution of sweet potato in the Ming and Qing dynasties. The total number for the literature review related to the economic and agricultural history of China is 31 , and each of these has been fully reviewed.

Some academic circles have also shown a continuous solicitude for the origins of sweet potato in China since the establishment of the PRC, with a relatively stable number of academic articles and even several research milestones (Fig. 1). Researchers have come to recognize the importance of the introduction of American cereal crops in China. Three major research phases can be established for this topic.

The first phase is from 1949 to 1966, starting with $\mathrm{Hu}$ Xiwen 胡锡文 (1958), who conducted a relatively complete discussion about the origin, distribution and cultivation techniques of sweet potato based on the agricultural books from the Ming and Qing dynasties and zhōngguó dìfâng zhì 中国地方志一Local Gazetteers of China. Thereafter, notable articles, which were published successively on material culture and the introduction and 


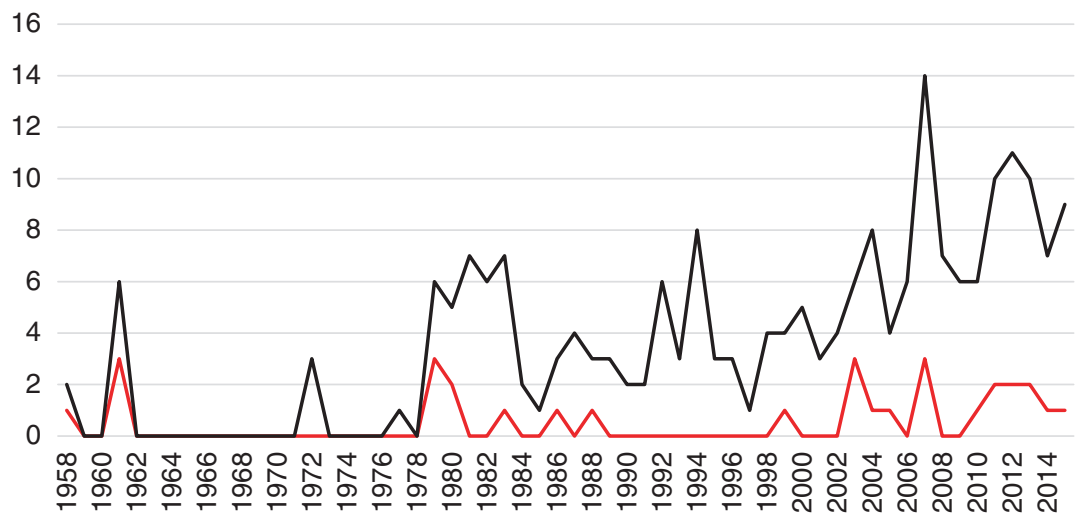

-Economic History _ Natural Sciences \& Economic History

Fig. 1 The trend of academic articles on the research of the introduction of sweet potato (1958-2015). Source http://ss.zhizhen.com/s.do?sw=番薯+传 $\lambda \& g_{0}=\mathrm{q}$

origins of sweet potato by Wang Jiaqi 王家琦 (1961), Xia Nai 夏靦 (1961) and Wu Deduo 吴德铎 (1961), stirred up a debate about whether sweet potato is indigenous to China. However, the analysis of this research in this phase was still in its early stages. It did not provide enough in-depth exploration, and the field of research and the number of articles was also limited.

The second phase is from 1966 to 1978 . The whole of Chinese academia became bogged down because of some obvious political factors, due to the negative effects of the Cultural Revolution, and the research on sweet potato also declined without any further progress being made. The third phase started in 1978 and flourished in the 1980s with more representative publications on the introduction and distribution of American crops (mainly corn, potato and sweet potato) in China and their influence in the economy; consequently, research by $\mathrm{He}$ Bingdi 何炳棣 (1979), ${ }^{3}$ Chen Shuping 陈树平 (1980), Guo Songyi 郭松 义 (1986) and Cao Shuji 曹树基 (1988) stood out. This new type of analysis contributed to some improvement in terms of the quality and results in the research. By the 1990s, researchers were focusing on the cereal crops' overall influence on the whole of society with multi-angle and multi-level considerations, which was shown in the works of Min Zongdian 闵宗殿 (1991), Zhang Jian 张箭 (2001), Lan Yong 蓝勇 
(2001) and Li Yingfa 李映发 (2003). From the first phase until today, scholars have further studied the introduction of American crops in China providing more historical evidence. However, academic debates are still ongoing on some important problems and limits in the research. This chapter briefly reviews the academic research in this field with the aim of first introducing the existing results and debates of four perspectives of the primary research and then concluding with a discussion for further studies.

Debin Ma has made a great contribution in terms of reviewing the evolution on economic studies and models of economic growth in Chinese academic circles, mainly from the second half of the twentieth century until now (Ma 2004a, b). Ma's work offers a major revisionist thesis on economic growth in China for the eighteenth and nineteenth centuries, incorporating within the analysis traditional social and political institutions in order to understand the path of long-term economic growth or stagnation in China.

As can be observed in Fig. I and as attested to by Debin Ma (2004a), in the 1980s, studies on Chinese economic history reached a more mature phase. This was a period of recovery and new intellectual blossom after the shock of the Cultural Revolution (Xu Dixin and Wu Chengming 1993). Such a period of openness was also evidenced through a renewed interest by several overseas scholars in the study of the uniqueness and evolution of long-term economic growth in China. This opened the door for the California School, several scholars specializing in the Chinese economy mainly led by Pomeranz, Blaut, Lee, Goody, Marks, Bin Wong and Von Glahn, among others (Vries 2010), centering the debate on the revisionist thesis on the economic growth of China during the eighteenth century. However, as Debin Ma recalled in his paper (Ma 2004a: 260), such debates generally took place outside China. Even though the 1980s saw a relaxation in the control over scholarly works and intellectuals, the constraints within Chinese academia were still rigid. For this reason, rather than focusing on the evolution of Chinese studies in general, ${ }^{4}$ the pioneering works being produced by overseas scholars, this chapter centres more on the analysis of the evolution of studies on sweet potato in Chinese historiography. The field of humanities and history has been traditionally relegated to a secondary position in Chinese society. However, in recent years we have witnessed a renaissance in the area of historical studies, whose major purpose is to follow mainstream and government policies. Such policies emphasize the implementation of the concept of 
'soft power' and culture to present in the international arena the longlasting and unique Chinese civilization. A new national history (or histories) in China has gained new ground, an example of this are the current projects of the Chinese government on the New Silk Road, referred to as 'One Belt, One Road' yīdài yīlù 一带一路. Such a project aims not only to develop investments and infrastructures, but also to promote Chinese culture in line with Chinese 'soft power' policies.

Revisionist theories on China's long-term stagnation, mainly published in Chinese by Li Bozhong, argue that the obsession in searching 'sprouts of capitalism' in China, by which the European exceptionalism and economic model applied to China might be observed, has misled the analysis of the Chinese economy (Li Bozhong 1998). I agree with Li's (1998) explanation mentioning that such an obsession could be explained by 'a profound inferiority complex, qíngjié (情结), developed in the Chinese public psyche from China's perceived backwardness relative to the West since the mid-nineteenth century' (Li Bozhong 2002). The perception of Western aggression in China has contributed to perpetuating in the Chinese public psyche the idea of blaming Westerners for the failure to modernize the country. Such perception mainly took place after the Opium Wars and the failures of China to modernize and internationalize the country in the same way than Japan did during the Meiji Restoration by successfully maintaining its traditional East Asian essence. The Tongzhi Restoration in China failed to fully implement its reforms (Westad 2012). The imposition of unfair treaties and local uprisings from northern to southern regions, provoking disunity and instability in the country from the nineteenth to the twentieth centuries, contributed to forming a nationalist narrative. Such patriotic schemes took form following the May Fourth Movement of 1919, in which we find for the first time the modern use of China as a national concept. Today this national renaissance can be observed through Xi Jinping's policy of the 'Chinese Dream', zhōngguó mèng 中国梦, which has notable echoes in academic circles.

Such perceptions, framed by an obvious national and patriotic mindset, were reinforced in the years after the foundation in 1949 of the PRC through two major periods of great disaster and economic instability: the Great Leap Forward (1958-1960) and the Cultural Revolution (19661976). These years form the benchmark of the CCP consolidation, political control and repression of intellectuals (Fairbank and Goldman 2006: 343). This obviously created the psychological ground regarding 
any intellectual form of 'Western characteristics' as potentially damaging for the nation. Some Chinese intellectual circles, through overseas experiences, have shaken off such a traditional mentality. This mindset, with some nuances, still exists today in Chinese academia and its own road to engaging internationalization within 'Chinese characteristics', zhōngguó tèsè 中国特色 (Li Wang 2014). This gives some insights into observing the penetration of global history in China at two levels: (1) totally ignoring the field, not repressing or banning it explicitly as in past times, but using other levels of repression, such as not funding projects on global history and relegating the field to a marginal level; or (2) in relation to those who pay attention to global history are hugely criticized by the Chinese Marxist School. Traditional Marxists of China see the field of global history as 'neo-colonialist strategy' that can potentially contaminate the meaning, concept and narrative of Chinese history and civilization. For this reason, global history is constantly transformed and manipulated within a nationalistic agenda (Wang Yunlong 2002: 121).

Such preconceptions and theoretical frameworks might give us some clues as to why studies and analysis within a clear global perspective have been transformed within a national narrative. This is the case for the analysis of circulation and diffusion of overseas commodities such as the introduction of agricultural crops of American origin to China, and in particular the case of sweet potato. Analysis of the period from the 1950s to the 1970s emphasizes the fact that such crops are indigenous to China. New narratives follow this pattern, stressing the importance of national consumption through a process of nationalizing overseas commodities such as sweet potato, which contributed from dynastic times up to the present day to the development of the Chinese national economy and agriculture.

\section{The Origin of Sweet Potato in China}

Generally, academia acknowledges that sweet potato was introduced to China under the Ming dynasty. However, opinions were divided about whether sweet potato was indigenous to China before the introduction and whether the gānshŭ (甘薯) in the ancient books is same as sweet potato. Most scholars (Ding Ying 1928; Hu Xiwen 1958; Liang Jiamian 1980; Cao Ling 2003) regard them as different species; sweet potato was introduced from America in a relatively short time. On the contrary, some researchers (Wang Jiaqi 1961; Zhou Yuanhe 1983) insisted that they are the same. 
For those who believe that sweet potato is indigenous, the ancient books are the most important source. Wang Jiaqi (1961) held the opinion that China had historical evidence about sweet potato even before the Ming dynasty and that the earliest source was in Yangfu's The Yiwn Zhi (异物志, literally, Record of Foreign Matters) in the Eastern Han dynasty and in Jihan's The Nanfang Caomu Zhuang (南方草木状, literally, Plants of the Southern Regions). The Yiwu Zhi said: "The sweet potato is like taro, and its flesh is white as fat... The southern people regarded them as rice." In Nanfang Caomu Zhuang, it is clearer that: "The sweet potato tastes like Dioscorea Opposita." These records do not only name it as "sweet potato", but also provide an unambiguous description of its shape, size, feature, planting and harvesting, which proved that was not recorded as "Dioscorea Opposita". Zhou Yuanhe (1983) carried out a similar analysis and inferred that sweet potato enjoyed a long history in China, even back to the Han and Jin dynasties. Yuanhe (1983) mentioned that during the Jin dynasty some improvements were introduced for the cultivation of this crop. This is naturally the literature that, mainly from the 1960s onwards, echoing the political mainstream prompted by the Cultural Revolution movement, tended to build a national narrative in terms of historical analysis.

Nevertheless, in recent decades within the framework of the period of political openness, scholarship embraced new theories and, therefore, more evidence seems to support the opinion that sweet potato was introduced to China from overseas. The two strongest pieces of supporting evidence for this are from modern science and the ancient Chinese scholar Xu Guangqi 徐光启 (1562-1633). At the beginning of the seventeenth century, $\mathrm{Xu}$ returned to his hometown, Shanghai, and, as Needham suggested (1984), he experimented with Western techniques of irrigation to cultivate sweet potato. The scientists found wild relatives of sweet potato in Mexico and Guatemala, which had been crops as early as 3000 BCE. In the 1960s, some root block relics of sweet potato were discovered in Peru (Zheng Nan 2013). This case demonstrates that the origins of sweet potato is from the New World. In addition, Xu Guangqi, the pioneer of promoting the planting of sweet potato in China, made a scientific summary that "there are two kinds of potato (shu), one is the Dioscorea fordii Prain et Burk (mountain potato) which is indigenous in Guangdong and Fujian, the other one is the Ipomoea batatas (sweet potato), which is introduced from overseas". 
Based on irrefutable evidence, most scholars tend to support the position that sweet potato was not indigenous to China, but was introduced under the Ming dynasty. However, some disputes on its origin remain, which is important for further research and discussion (Fig. 2).

\subsection{Introduction: The Timing and Route of Sweet Potato}

The knowledge of the Americas in China, through travellers, seafarers, stories or myths describing the first contacts with the New World, more specifically New Spain (Mexico), was casual and without any delimited plan for a conquest, as was the case for the European enterprise towards the Americas. Despite the possible introduction of Chinese material culture and contacts in the Americas before the arrival of Columbus, this does not mean that there was a 'Chinese discovery' of the Americas. It was through the Manila-Acapulco galleons that knowledge and communication between both continents was stimulated through the circulation and introduction of new commodities such as sweet potato, among others. These accounts provide evidence that sweet potato was introduced in China at the end of the Ming dynasty in 1594 (Goodrich 1937). In fact, consciously or unconsciously, Chinese scholarship has acknowledged 1594 as the year of the introduction of sweet potato in China following the suggestions made in the pioneering work of Goodrich (1937). Goodrich also suggested that sweet potato likely entered China from the island of Luzon, Malaysia or the South Seas. However, he did not give much empirical evidence to prove this (Goodrich 1937). Having this research as a point of departure, Fujian (福建) and Guangdong (广东) provinces have been widely accepted as the main areas where crops of American origin, such as sweet potato, entered China.

There is unanimity in the opinion that sweet potato was brought into Fujian (福建) territory through maritime trade. A re-examination of this theory through Fujian (福建) and Yunnan (云南) historical sources suggests that there was an early introduction of sweet potato via the Yunnan (云南) region (Ping-Ti Ho 1955). One of the major reasons why the year of 1594 has been widely recognized as the year of the introduction of sweet potato in China is because a famine took place that year. Therefore, this crop attracted the attention of political authorities and the governor of Fujian (福建). The governor distributed pamphlets on methods for extensive cultivation to eradicate famine (Ping-Ti Ho 1955). Consequently, in early scholarly research of the twentieth century 

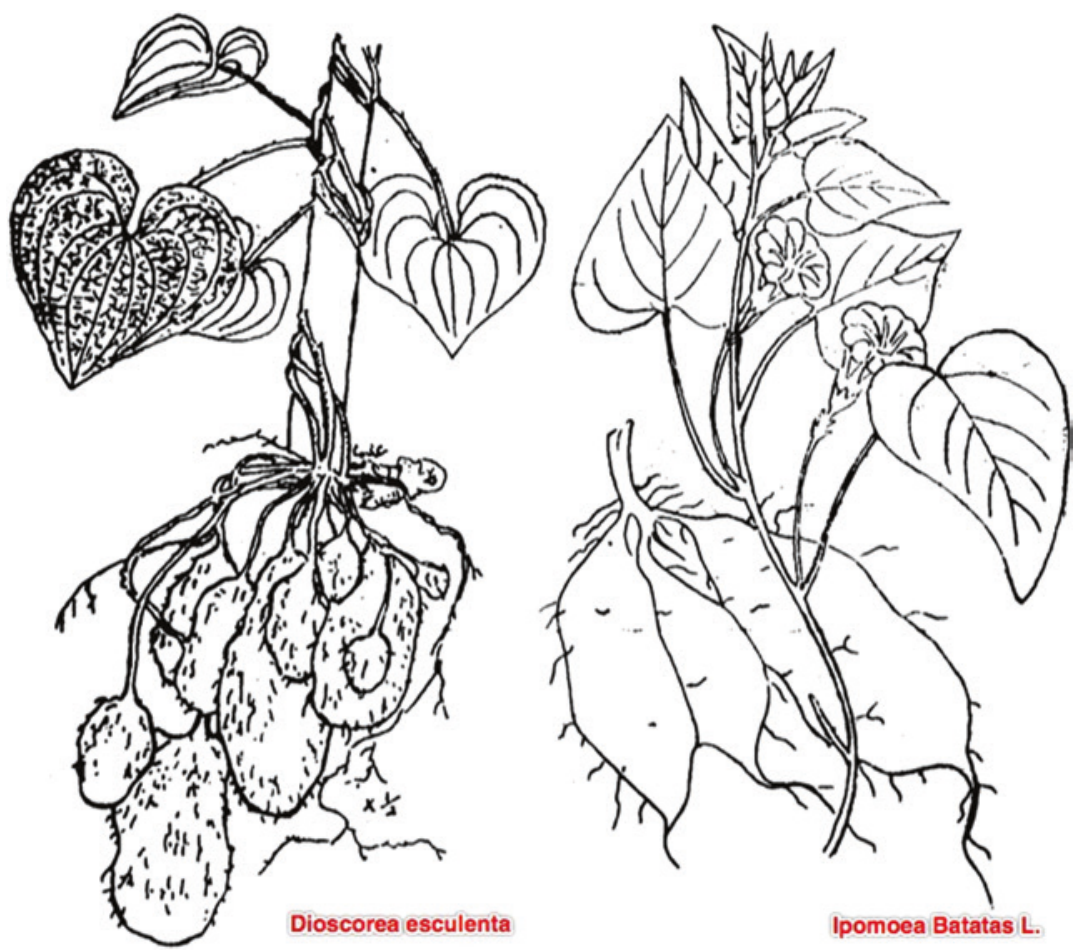

Fig. 2 Two kinds of potato: Dioscorea Esculenta and Ipomoea Batatas. Source Liang Jiamian, Qi Jingwen (1980)

(Goodrich 1937; Ping-Ti Ho 1955), two main channels for the introduction of sweet potato into Jiangsu (江苏) and Fujian (福建) provinces were widely accepted. The route of Fujian (福建) province is the one that has gained more support: i. in Changle (长乐) county, in Fujian (福 建) province, near Fuzhou (福州), sweet potato was introduced through merchants from Luzon (Philippines). ii. another route for the introduction of sweet potato was through the urban area of Changzhou (常州), in southern Jiangsu (江苏) province. Locals claimed that the first introduction of sweet potato was into this locality and was kept a secret. There are no sources to corroborate this evidence or the year when it was introduced in Changzhou (常州); therefore, this cannot be considered a plausible option. 
Based on the consensus that there was a type of sweet potato introduced into China, scholars should focus more on the timing and route of its introduction, since there is still a lively debate as to when, where and how this commodity reached inland China. The debate in the second half of the twentieth century was covered by a national and patriotic narrative mainly by those who sustained that sweet potato was indigenous to China by presenting alternative routes of introduction. Some scholars tend to consider that there were three main routes (Liang Jiamian and Qi Jingwen 1980), but another group of researchers offers more possible routes (Cao Ling 2003; Zheng Nan 2010).

Liang Jiamian and Qi Jingwen (1980) analysed several ancient books and county annals and pointed out that there were three main routes. The first one is mentioned by Lin Huailan, who affirmed that sweet potato was introduced from Vietnam (Jiaozhi 交趾) to Dianbai (电白) county. Lin Huailan was a doctor who saved the princess of Vietnam and was granted food, which included sweet potato. Lin transported it back to China secretly. There was even a temple to commemorate Lin (Annals of Dianbai county; Annals of Guiping county). However, the experience was so legendary that some scholars also suspect that these records may be far-fetched. The second one is the transportation of sweet potato by Chen Yi from Vietnam (Jiaozhi 交趾) to Dongguan (东莞). In 1580, Chen Yi travelled to Vietnam (Annan 安南) by boat and was encountered sweet potato. He obtained the seeds by bribing the chief of a tribe and escaped back in 1582 to Dongguan (东莞) county, Guangdong (广 东), because sweet potato was banned from export as it can be observed in the genealogy of Chen in Fenggang (凤岗) village. The third one was Chen Zhenlong's attempt, which was also the most influential one. Chen lived in the Philippines (Lv Song 吕宋) for a long time and knew that sweet potato was good to improve the standards of living in the same way as the five cereals. Thus, he brought it back to Fujian (福建) in 1593 and planted it successfully. In addition, it is important to mention that sweet potato was distributed to other provinces in China with the help of the government and Chen's descendants (Li Yuan 2011).

Cao Ling (2003) and Zheng Nan (2010) mentioned more possible routes, quoting other ancient books. One route was from the Philippines to Changzhou (常州) in the mid-Wanli era mentioned in the book Min Xiaoji by Zhou Lianggong 周亮工 (1612-1672). Another route was from overseas to Nan'ao (南澳) and Quanzhou (泉州) in 1584-1585. 
Gongsun Jian also clarified a similar opinion about two alternative routes. Besides the sea route, a land route also seemed helpful to the introduction of sweet potato. Based on the records in the General Annals of Yunnan (1574) and the Annals of Dali (1563), He Bingdi (1979) deduced that sweet potato could be introduced into China from Burma at that time (Table 1).

Traditional Chinese scholarship has insisted in this via for the introduction of sweet potato in China (Ping-Ti Ho 1955). This is an overland route from India and Burma, by which Chinese scholarship remarks that sweet potato reached Yunnan (云南) province before 1594. The local history of Yunnan (云南) suggests that sweet potato is indigenous to this region. Local sources mentioned that sweet potato was under the name of red tuber, hóngshŭ (红薯) or red taro, hóng yù (红芋), “in contrast to native Chinese yam, which was clearly identified as dioscorea (shān yáo 山瑶)" (Ping-Ti Ho 1955). Ping-Ti Ho (1955) makes this clear affirmation, suggesting that this yam was indigenous to China, and later he contradicts himself, suggesting that there is no clear evidence of the year and routes of introduction, whether from Fujian (福建) or Yunnan (云南). In addition, in the event that sweet potato was introduced from Yunnan (云南) via Burma and India, it is plausible to consider that it reached these areas via maritime trade from the Philippines through the Manila-Acapulco galleons.

Although scholars have arrived at a consensus on the existence of several routes for the introduction of sweet potato into China, only Chen Zhenlong's efforts received recognition from the whole of academia. The existence of five other complementary routes was questioned for the following three reasons: (1) the records in the local annals and genealogy probably exaggerated the facts (Cao Ling 2004), so it would be scientifically unsustainable to recognize an alternative route for the introduction of sweet potato without any other supporting material-in this case, Liu Huailan and Chen Yi's introduction of sweet potato from Vietnam around 1582 called for more circumstantial evidence; $(2)$ the transcription of historical books is usually accompanied by anachronisms, even though the first recorder's account was based on solid fact-for example, the description of sweet potato in Zhou Lianggong's Min Xiaoji was not written by himself, but was derived from He Yuanqiao's Min Book. Zhou only changed some words, but according to his writings it is very 
Table 1 Period and areas of introduction of sweet potato in China during the Ming Dynasty

\begin{tabular}{|c|c|c|c|}
\hline Time & Place & Name & Original record \\
\hline Before 1582 & $\begin{array}{l}\text { Dongxia village, Dianbai } \\
\text { county, Guangdong } \\
\text { province }\end{array}$ & Lin Huailan & $\begin{array}{l}\text { Annals of Dianbai county; } \\
\text { Annals of Guiping county }\end{array}$ \\
\hline 1582 & $\begin{array}{l}\text { Fenggang village, } \\
\text { Dongguan county, } \\
\text { Guangdong province }\end{array}$ & Chen Yi & $\begin{array}{l}\text { Genealogy of Chen in } \\
\text { Fenggang village }\end{array}$ \\
\hline 1593 & $\begin{array}{l}\text { Changle county, Fujian } \\
\text { province }\end{array}$ & Chen Zhenlong & $\begin{array}{l}\text { Instructions for Practical } \\
\text { Living of the Sweet Potato } \\
\text { (金薯传习录 Jinshu } \\
\text { Chuanxilu) }\end{array}$ \\
\hline
\end{tabular}

Source Liang Jiamian and Qi Jingwen (1980)

difficult to establish the timing in which sweet potato was introduced; (3) the records might mistake Dioscorea Opposita as sweet potato. For instance, Li Debing and He Baolin do not agree with He Bingwen's thesis of Burma as main route for the introduction of sweet potato because Bingwen fails in identifying different typologies of potato. Furthermore, researchers are still not certain about the existence of sweet potato in Burma at that time. To sum up, there are six possible routes for the introduction of sweet potato based on ancient books, but only the route suggested by Chen Zhenlong has gained recognition. The other five routes, and their possible chronologies, require more research and empirical evidence to support them.

\subsection{The Distribution of Sweet Potato}

In relation to the distribution of sweet potato, researchers focused on different aspects. In 1980s, He Bingdi (1979), Chen Shuping (1980) and Guo Songyi (1986) concentrated more on the progress of the distribution from a macro-perspective based on the local annals. Similarly, Zhou Yuanhe (1983) summarized several routes. From the 80s onwards, scholars emphasized the progress of the distribution in different provinces and the research went further (Guo Songyi 1986). The following lines will first offer general information on the progress of the 
distribution of sweet potato, then will describe the map routes, and finally will provide some discussion about the dynamics of its circulation.

There is agreement among most scholars that it did not take much time for sweet potato to be accepted by Chinese communities once it was introduced. It had become widely planted in Fujian (福建) and Guangdong (广东) province at the end of Ming dynasty. It was introduced into Jiangxi (江西) province, Hunan (湖南) province, Zhejiang (浙江) province and Jiangsu (江苏) province in the latter half of the seventeenth century. In the mid-eighteenth century, it had spread over all southern provinces and had extended its range to the Yellow River basin and the northern provinces.

In this case, there were four channels for the internal diffusion of sweet potato from Guangdong (广东) province and Fujian (福建) province to the west and north (see Map 1). The first channel (the red line on the map) could be labelled as the coastal route from Fujian (福建) reaching inner China. This route went from Quanzhou (泉州) to Changle (长乐), the Yuhuan island (玉环岛), Wenzhou (温州), Taizhou (台州), Danxian (部县), Zhoushan (舟山), Shanghai (上海), Shangdong (山东), Henan (河南) and up to Hebei (河北). The second channel (the yellow line on the map) could be named the Guangdong-Jiangxi route (广东-江西), and it went from Dianbai-Guangzhou (电白-广州) to Shaoguan (韶关), Meiling (梅岭), Dayu (大余), Ganzhou (赣州) and Nanchang (南昌). The third channel can be named Guangzhou-Zhongyuan (广州-中原) following the Central Plain route; see the blue line on the map) and it went from Guangzhou (广州) to Shaoguan (韶关), Pingshi (坪石), Chenxian (椰县), Hengyang (衡阳), Changsha (长沙), Yueyang (岳阳), Wuchang (武昌), Nanchang upland (南昌高地) and to the Central Plain (中原区 域). Finally, the fourth channel, the Guangzhou-Guizhou (广州-贵州) route (the purple line on the map), went from the Zhujiang River Basin (珠江流域) to Guangxi (广西) province and Guizhou (贵州) province. Zhou Yuanhe also suggested an alternative route, as mentioned earlier, from Burma and Vietnam to Yunnan (云南), Guizhou (广州) and north to Sichuan (四川), which was not documented clearly, and no other scholars support this theory. The east coastal channel from Fujian (福建), reaching the inner regions of China, has been established as the main route.

After the introduction and distribution of this crop, the range of cultivation of sweet potato had spread across a very large area at the end of the Qing dynasty. Nevertheless, there was an obvious centralized distribution in Guangdong (广东) province and Fujian (福建) province, the 


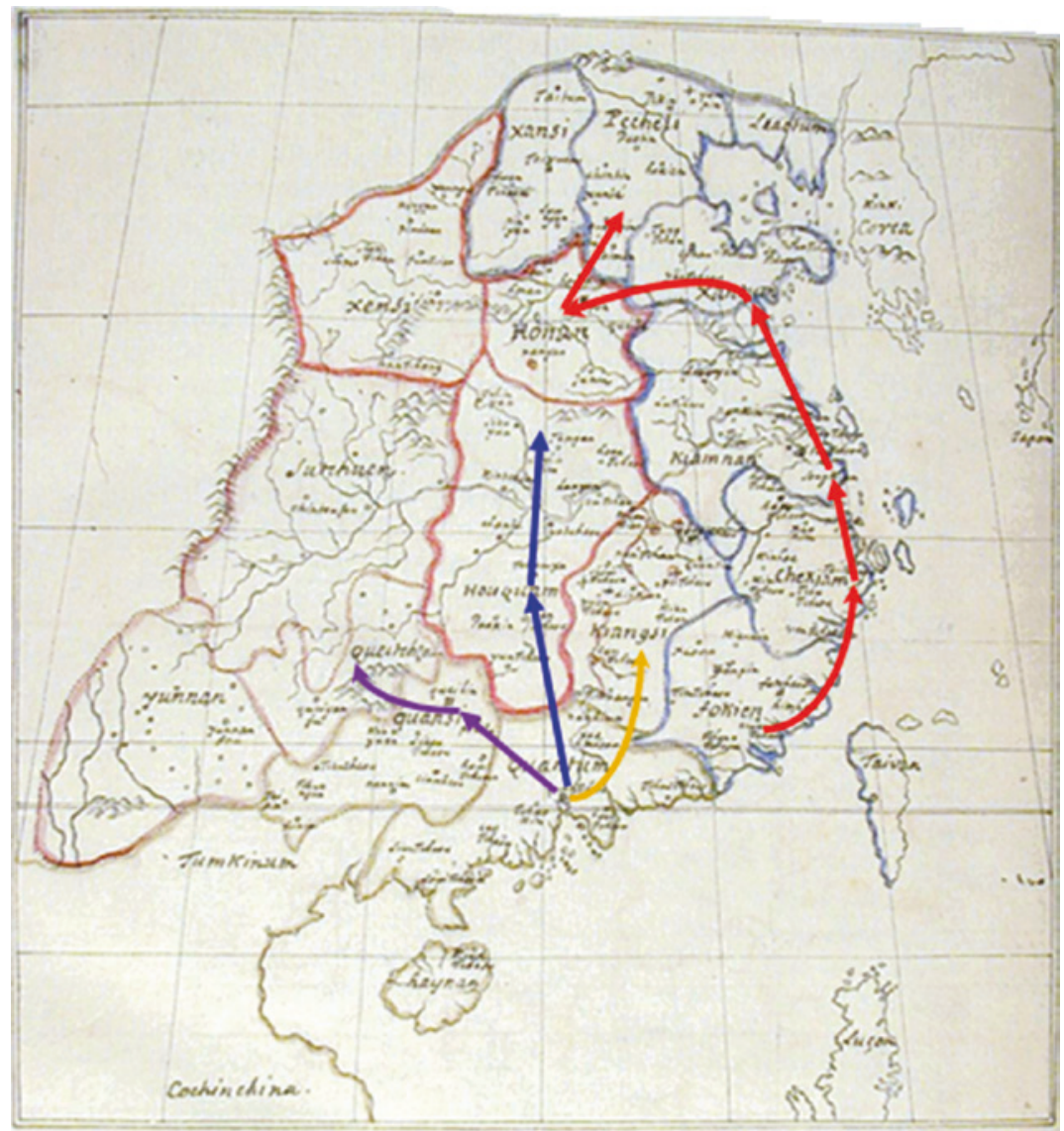

Map 1 Routes of Distribution of Sweet Potato in Ming China. Source Archive of Matteo Ricci Institute of Macau (Archivum Romanum Societatis Jesu), Jap. Sin. 181, Epistola Sinarum, f. 001

southern hill region in Fujian (福建) province, Zhejiang (浙江) province, Jiangxi (江西) province and Anhui (安徽) province, the mountainous area in Hubei (湖北) province and Hunan (湖南) province, the Sichuan (四川盆地) Basin and the southern centre of Shandong (山东) province.

Looking back at the process and timeline of the introduction and distribution of sweet potato, there are two important factors that contributed to its rapid diffusion: (i) the rising levels of consumption for this commodity in the areas where it was first introduced; and (ii) its growth 
enriched the farming land and allowed improvements in the techniques of cultivation. For the introduction of sweet potato in the period of Emperor Wanli (万历) during the Ming dynasty, academia generally agrees that there are four factors which fostered its diffusion (Zheng Nan 2010; Chen Lili 2007; Ouyang Chunlin 2012; Luo Shujie 2014): (i) the channels of transportation were relatively developed compared to previous generation and the number of international contacts had multiplied; (ii) it was a commodity that due to its rich nutrients, such as carbohydrates, improved standards of living, provoking a growth in the population; (iii) the annexation of land by imperial elites and the power of the despotic gentry became more violent, having as a result the loss of lands by peasants (Zheng Nan 2010; Chen Lili 2007; Luo Shujie 2014). This factor might be somehow simplistic, and made by traditional PRC scholars, since obviously for landlords and imperial elites, the management and entire tenancy of land represented a strong instrument for the exercise of power through heavy bureaucracy and institutions. Such scholarship should insist more on the negative effect of the role of institutions and bureaucracy rather than the linear and obvious result of elites obtaining more land and peasants losing it; (iv) in Guangdong (广东) province and Fujian (福建) province, the grain fields were much smaller in size because of the massive planting of cash crops and a food shortage emerged, which finally prompted people to look for other heavy yielders and to plant them on a large scale. However, the social unrest at the end of the Ming dynasty and the overwinter problem of sweet potato in the northern area hindered the spread of it at that time.

When it comes to the factors for the concentrated distribution of sweet potato in the Qianlong and Jiaqing periods (乾嘉时期), opinions are divided. Some scholars hold that the spread of sweet potato was the crucial watershed for population growth and improvements in cultivation techniques in China (He Bingdi 1979; Cao Ling 2003, 2005; You Xiuling 2003; Chen Zhongqi 2012). There are some factors which might explain it. First, the high pressure of population growth and the resulting increase in demand for food. For instance, migration during the Qing dynasty played an important role in the distribution of sweet potato in Sichuan (四川) province. The high yield of sweet potato and its great help in times of drought were fully recognized by the government, which also prompted its distribution. The improvement in overwinter techniques of cultivation was another important reason for the planting of sweet potato in the Yellow River basin. 
Conversely, Wang Baoning (2013), who focuses his research on the distribution of sweet potato in Shandong (山东) province, claimed that the main reason for its rapid diffusion was to combat natural disasters. But he did not relate this directly to the high pressure exerted by the growth in population. In addition, the scale of planting sweet potato only extended in some local areas. In this case, Wang argues that there were not sufficient conditions for the effective distribution of sweet potato. In general, the main debate on the distribution of sweet potato has focused on factors that contributed to its rapid assimilation in the territories where it was first introduced, improving local economies. Different assumptions such as its influence on the population pressure and disaster relief might need further discussion.

\section{The Influence of Sweet Potato on Agricultural Production and the Social Economy}

There is a lacuna in the academic writing on the influence of sweet potato in China. Nevertheless, some discussion can also be found in articles on the introduction and distribution of American-originated crops, which are mainly concerned with their influence on Chinese agriculture, the social economy, population and the ecological environment. He Bingdi (1979) deemed that the introduction of corn and sweet potato led to a systemic long-term change in Chinese land utilization and grain production, and this marked the second revolution in Chinese grain production history. The book Grain Yield per Mu of the Qing Dynasty (Zhao Gang et al. 1995) showed the role of corn and sweet potato in boosting the grain production in the late Ming and early Qing dynasties and the consequential damage caused to the environment, which in turn brought about the decline in grain production later.

The introduction of American crops increased the farmland in central and south-western China during the Qing period. For instance, the characteristics of sweet potato, such as flood resistance, endurance of drought and high adaptability, made it survive in coastal sandy land and poor mountain soil, which meant more land could be used for its cultivation. Other crops such as corn and potato have the same quality. Table 2 shows that the farmland in central and south-western China in the Qianlong (乾隆) and Jiaqing (嘉慶) periods nearly doubled compared to the early Qing dynasty. At that time, corn and sweet potato were rapidly distributed in these provinces (Ma Xueqin 1999; Wang Shengpeng 2015). Thus, 
corn and sweet potato played an important role in the expansion of the cultivated area. The use of farmland did not increase much from Jiaqing (嘉慶) to Guangxu (光緒) periods due to the decline in population and limited expansion of new land. In addition, American crops have high yielding per $m u$ improving the land-use mainly in areas non-specialized in agriculture (Table 3 ). Thus, the gross output of grain of China increased dramatically at that time.

Chen Shuping (1980) analysed the influence of American crops on the socio-economic development of Chinese territory. On the one hand, the introduction of sweet potato raised grain production and extended the plantation area. On the other hand, it also contributed greatly to the planting of cash crops and the commercialization of food production, which promoted the handcraft industry and commerce.

The introduction of sweet potato seemed to have some negative effects on the long-term Chinese socio-economic development (Huang Fuling 2011; Song Junling 2007). Lan Yong (2001) focused on the

Table 2 The field area statement in Central China and Southwestern China in the Qing Dynasty (units: $1000 \mathrm{Mu}$ )

\begin{tabular}{lllll}
\hline & $\begin{array}{l}\text { Shunzhi } 18 \text { years } \\
(1661)\end{array}$ & $\begin{array}{l}\text { Qianlong } \\
\text { 18 years }(1753)\end{array}$ & $\begin{array}{l}\text { Jiaqing } 17 \text { years } \\
(1812)\end{array}$ & $\begin{array}{l}\text { Guangxu } \\
\text { 13 years (1887) }\end{array}$ \\
\hline $\begin{array}{l}\text { Hunan \& } \\
\text { Hubei }\end{array}$ & 79,335 & 90,755 & 92,100 & 93,950 \\
Sichuan & 1188 & 45,957 & 46,547 & 46,417 \\
Yunnan & 5211 & 7543 & 9315 & 9319 \\
Guizhou & 1074 & 2573 & 2766 & 2765 \\
Total & 86,808 & 146,828 & 150,728 & 152,451 \\
\hline
\end{tabular}

Source Liang Fangzhong (1980). $M u$ is a Chinese unit of land area equivalent to approximately onesixth of an acre

Table 3 The yield and increment of corn and sweet potato in the Qing Dynasty

\begin{tabular}{lll}
\hline & Yield per Mu & Increment per Mu \\
\hline $\begin{array}{l}\text { Corn } \\
\text { Sweet Potato }\end{array}$ & $\begin{array}{l}\text { 180 Jin (equivalent to 2 Dan of millet) } \\
\text { rice and 3.09 Dan of millet) }\end{array}$ & $10.37 \mathrm{Jin}$ \\
& 10.77 Jin \\
\hline
\end{tabular}


Chinese subtropical mountain areas. This scholar considers that the introduction of American high-yielding crops led to a continuous population growth (see Fig. 3), which initiated the mountain exploitation under the Qing dynasty and later caused the structural poverty and limited commercial economy in these areas. During the Ming-Qing transition in the first quarter of the seventeenth century, an important decline in population occurred due to wars and a dynastic crisis, which resulted in famines, floods, economic chaos and rebellions (Bin Wong 1997). However, as it can be observed in Fig. 3, a steady growth in the Chinese population continued following the introduction of sweet potato at the end of the sixteenth century until the nineteenth century. He Bingdi (1979) held the opinion that the introduction of American crops, the revolution of the grain production and the population explosion jointly interacted as causes and effects. Wang Yumin and Jiang Tao sustain the same argument. Ge Jianxiong considered these agricultural improvements as the significant reason for the population miracle (Song Junling 2007). Zhang Jian (2001, 2013) and Zhang Gang (1955) recalled that the negative effect of the high-yielding crops on the environment should not be ignored. Zhang Gang (1955) stated that the exploitation of the mountain led to the fatal destruction of the ecological balance, including the deforestation, soil erosion, farmland desertification and frequent

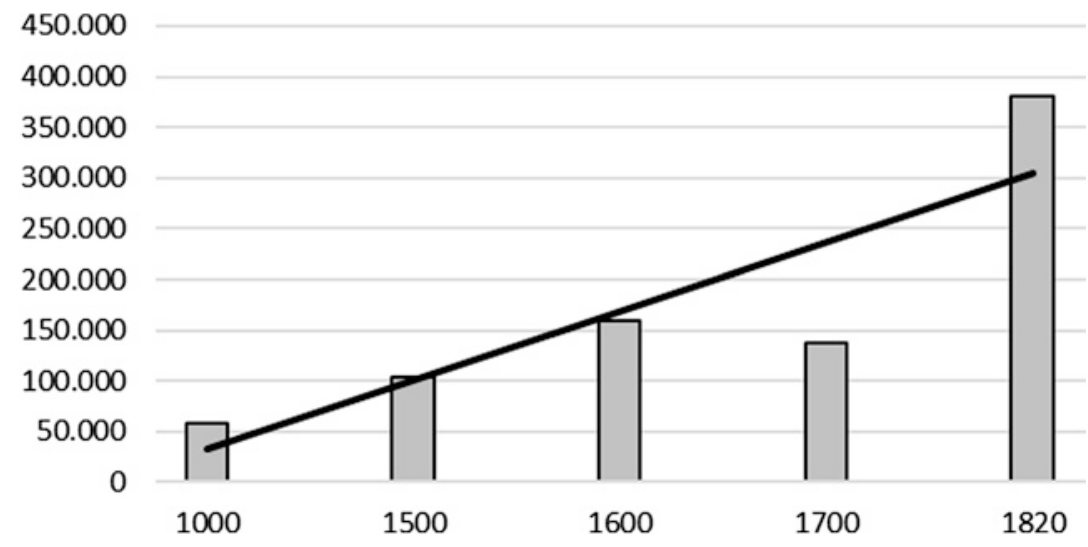

Fig. 3 Population growth in China from 1000 to 1820. Source Maddison Project, http://www.ggdc.net/maddison/maddison-project/home.htm, 2013 version; Maddison $(1995,2001,2003)$ 
floods, which finally resulted in a decreasing grain yield (Cao Ling 2004).

\section{Conclusions}

Based on the literature review, it can be considered that Chinese academia still has a long way to go in terms of further analysing the introduction and distribution of sweet potato in China. Some disputes remain, as it has been mentioned above, since patriotic narratives aim to nationalize commodities that entered China from the Americas and therefore to make them indigenous.

Nevertheless, the research and discussion on the role of sweet potato in early modern China could be deepened. An important group of scholars still focuses on American high-yield crops and has given little consideration to the influence of sweet potato itself (Cao Ling 2004; Song Junling 2007). In addition, there is a lack of long-term historical analysis that can provide a fuller perspective. Current research also separates China from its global connections by only concentrating on the Chinese internal agricultural revolution and economy, with the clearly nationalistic and patriotic aim of presenting the long-standing civilization and uniqueness of China. However, relying on the influence of sweet potato and other cereal crops introduced from the Americas, the analysis of the different models of economic growth in China and the West and the great divergence debate could be enriched by observing how China's consumers, market and political choices affected its development and destiny in the early modern era when Europe forged ahead during the first Industrial Revolution.

The most important reason for this inefficiency is the lack of multidisciplinary research and analysis, as well as the void in international academic communication, as most researchers have focused on this issue through the study of Chinese agricultural history, mainly due to the political context that existed from the 1960s to the early 1980s. Obviously, I am referring here to PRC scholarship and not to that carried out by Chinese overseas and Western scholars, whose work has been fruitful in terms of results and academic discussions. Therefore, in Chinese scholarship achievements nowadays, the scope of research is still quite limited. In this case, more effort should be made to promote interdisciplinary research embracing global history without 'Chinese national 
characteristics', which obviously obscures pure academic results without any type of manipulation, revealing new perspectives and diverse realities.

\section{Notes}

1. The concept of the CNKI was proposed by the World Bank in 1998. The main objective of the CNKI is to create a database to share knowledge and resources with the whole of society, as well as value-added for applicable research to spread information to all public and private economic sectors. This project was initiated in June 1999 by Tsinghua University, with the strong support of the party and state leaders, the Ministry of Education, the Central Propaganda Department, the Ministry of Science and Technology, the General Administration of Press and Publication, the State Copyright Bureau and the State Planning Commission. Thus, it involves academic, educational, publishing, library and information circles, as well as the CNKI Engineering Group. The creation of this national and political-orientated leading digital library aims to include largest fulltext information, CNKI Digital Library, China Knowledge Resources and CNKI Grid Resource Sharing Platform to find solutions of current economic, political and social issues of China. This database stands out as a good source to observe how global history, and the analysis of the concept of being global in China through the introduction of foreign crops such as sweet potato, is penetrating in academic circles and challenging the current nationalist and patriotic agenda of the Chinese government.

2. Chāoxīng 超星 is a database providing library sources, with an orientation towards both an academic and a non-academic audience, to provide services for education and scientific research in China. The Ministry of Education supports this platform, which has similar objectives to the CNKI.

3. The work by $\mathrm{He}$ Bingdi 何炳棣 or Ping-Ti $\mathrm{Ho}$ is included here in Chinese scholarship since his research on the introduction of American crops in China, published in 1979 in the Chinese journal 世界农业 Shijie nóngyè, is a review of his former work published in 1955 in the American Anthropologist journal. He was an accomplished Chinese-American scholar who conducted outstanding work on Chinese history, mainly on demography and plant history. I will refer to him here as He Bingdi and will only refer to his name Ping-Ti Ho when quoting his work published in American Anthropologist.

4. For the sake of not repeating a long list of works, I will mention some of the most relevant, such as: Perkins (1975), Rawski (1989), Zurndorfer (1989), Wright (1992), Von Glahn (1996; 2016), Wong (1997), Maddison (1998), Deng (1999), Pomeranz (2000) and Ma (2004a). 


\section{REFERENCES}

An, Changchun. 1993. Cong shijieshiguan kan woguo shijieshi xueke jianshe [The Construction of the Field of World History in our Country regarding the Concept of World History]. Wuban daxue xuebao (Journal of Wuban University) 4: 13-18.

Berg, M. 2006. Britain, Industry and Perceptions of China: Matthew Boulton, 'Useful Knowledge' and the Macartney Embassy to China 1792-94. Journal of Global History 1: 269-288.

Cao, Ling. 2003. Meizhou liangshi zuowu de chuanru, chuanbo ji qi yingxiang chuanbo [Study on the Introduction, Spread and Affection of American Cereal Crops]. Master Thesis of Nanjing Agricultural University.

Cao, Ling. 2004. Ming Qing meizhou liangshi zuowu chuanru zhongguo yanjiu zongshu [The Overview of the Studies on the Introduction of American Cereal Crops in Ming Qing Dynasty]. Ancient and Modern Agriculture (2): 95-103.

Cao, Ling. 2005. Meizhou liangshi zuowu de chuanru dui woguo nongye shengchan he shehui jingji de yingxiang [Influence the Introduction of American Cereal Crops on Agricultural Production and Social Economy of China]. Ancient and Modern Agriculture (3): 79-88.

Cao, Shuji. 1988. Yumi he fanshu chuanru zhongguo luxian xintan [A New Investigation on the Path of the Introduction of Corn and Sweet Potato]. Research of Chinese Social and Economic History (4): 62-74.

Chen, Lili. 2007. Yuanyang taoci maoyi yu fanshu de yinzhong [The Ocean Trade of Ceramics and the Introduction of Sweet Potato]. Agricultural Archa (3): 26-31.

Chen, Shuping. 1980. Yumi he fanshu zai zhongguo chuanbo qingkuang yanjiu [The Studies on the Distribution of Corn and Sweet Potato in China]. Social Sciences in China (3): 187-204.

Chen Zhongqi. 2012. Shi lun Ming, Qing shiqi ganshu zai xinan diqu de chuanbo yu yingxiang [On the Distribution and Influence of Sweet Potato in Southwestern Area During Ming and Qing Dynasty]. Journal of Fuling Teachers College (11): 11-15.

Deng, Gang. 1999. The Premodern Chinese Economy: Structural Equilibrium and Capitalist Sterility. London and New York: Routledge.

Ding, Ying. 1928. Ganshu, jian suozhe "zuowu ming shi kao" di yibufen. Nong sheng (123).

Fairbank, J. K., and M. Goldman. 2006. China: A New History, 2nd ed. Cambridge, USA: Harvard University Press.

Goodrich, L.C. 1937. The Introduction of Sweet Potato into China. China Journal 27: 206-208. 
Guo, Songyi. 1986. Fanshu zai Zhejiang de yinzhong he tuiguang [The Introduction and Distribution of Sweet Potato in Zhejiang Province]. Zhejiang Academic Journal (3): 45-49.

He, Bingdi. 1979. Meizhou zuowu de yinjin, chuanbo ji qi dui zhongguo liangshi shengchan de yingxiang [On the Introduction, Distribution of American Crops and their Influence on Chinese Agricultural Production]. World Agriculture (4): 21-41.

Ho, Ping-Ti. 1955. The Introduction of American Food Plants into China. American Anthropologist, New Series, Vol. 57, No. 2, Part 1 (Apr.): 191-201.

$\mathrm{Hu}$, Xiwen. 1958. Ganshu laiyuan he women laodong zuxian de zaipei jishu [The Origin of Sweet Potato and Cultivation Technique of Chinese Forefather]. Journal of Agricultural Heritage (2): 21-32.

Huang, Fuling. 2011. Ming Qing shiqi fanshu yinjin zhongguo yanjiu [The Study on the Introduction of Sweet Potato into China during Ming and Qing Dynasty]. Master Thesis of Shandong Normal University.

Huang, Hui-Cheng, and M. Gove. 2012. Confucianism and Chinese Families: Values and Practices in Education. International Journal of Humanities and Social Science 2 (3) (February): 10-14.

Lan, Yong. 2001. Ming qing meizhou nongzuowu yinjin dui yaredai shandi jiegou xing pinkun xingcheng de yingxiang [The introduction of the Ming and Qing American Crops on the formation of subtropical mountain structural poverty]. Zhongguo nong shi (Chinese Agricultural History) (4): 3-14.

Li, Bozhong. 1998. Agricultural Development in Jiangnan, 1620-1850. New York: St. Martin's Press.

Li, Bozhong. 2002. Lilun, Fangfa, Fazhan Qusi [Theory, methodology and developmental trends]. Beijing: Tsinghua University Press.

$\mathrm{Li}$, Wang. 2014. Internationalization with Chinese Characteristics: The Changing Discourse of Internationalization in China. Chinese Education and Society 47 (1) (January-February): 7-26.

Li, Yingfa. 2003. Qing chu yimin yu yumi ganshu zai sichuan diqu de chuanbo [Migration in Early Qing Dynasty and the Transmission of Maize and Sweet Potato in Sichuan]. Zhongguo nong shi (Chinese Agricultural History) (2): $7-13$.

Li, Yuan. 2011. Ming Qing shiqi ganshu de yinzhong ji qi zai Shandong de tuiguang [The Introduction of Sweet Potato in Ming and Qing Dynasty and its Distribution in Shandong Province]. Journal of Shandong Agricultural University (Social Science Edition) (2): 82-87.

Liang, Fangzhong. 1980. The Statistics of the Household, Farmland and Land Tax of All the Past Dynasties in China. Shanghai: Shanghai People's Publishing House.

Liang, Jiamian, and Qi Jingwen. 1980. Fanshu yinzhong kao [On the Introduction of Sweet Potato]. Journal of South China Agricultural College (3): 74-79. 
Liang, Zhan-Jun. 2006. Quanqiu shi yu shijie shi yitong chuyi [Comparing World History and Global History: a Chinese Scholar's View]. Shoudu shifan daxue xuebao shehui kexue ban [Journal of Capital Normal University] (Social Sciences Edition) 3: 1-5.

Liu, Beicheng. 2000. The Challenges of Reconstructing World History. Shixuelilunyanjiu (Historiography Quarterly) 4: 67-69.

Liu, Shuang. 2002. The View of History and Methodology in the Process of Globalization. Xuexiyu Tansuo (Study and Exploration) 4: 121-126.

Luo, Shujie. 2014. Qingdai yumi fanshu zai guangxi de chuanbo chayi yuanyin xinjie [A New Interpretation of the Reasons of Diverse Spread of Corns and Sweet Potatoes in Guangxi During Qing Dynasty]. Journal of Guangxi University for Nationalities (5): 105-108.

Ma, Xueqin. 1999. Mingqing shiqi yumi, fanshu zai henan de zaizhong yu tuiguang [The Planting and Distribution of Corn and Sweet Potato in Henan Province in Ming and Qing Dynasty]. Ancient and Modern Agriculture (1): 49-53.

Ma, D. 2004a. Growth, Institutions and Knowledge: A Review and Reflection on the Historiography of the 18th-20th Century China. Australian Economic History Review 44 (3) (November): 259-277.

Ma, D. 2004b. Why Japan, not China, was the first to develop in East Asia: Lessons from sericulture, 1850-1937. Economic Development and Cultural Change 52: 369-394.

Maddisson, A. 1998. The Chinese Economic Performance in the Long-Run. Paris: OECD Development Centre.

Maddisson, A. 1995. Monitoring the World Economy 1820-1992. Paris: OECD Development Centre.

Maddisson, A. 2001. The World Economy: A Millennial Perspective. Paris: OECD Development Centre.

Maddisson, A. 2003. The World Economy: Historical Statistics. Paris: OECD Development Centre.

Marks, Robert B. 1998. Tigers, Rice, Silk \& Silt: Environment and Economy in Late Imperial South China. Cambridge: Cambridge University Press.

Min, Zongdian. 1991. Haiwai nongzuowu de chuan ru he dui woguo nongye shengchan de yingxiang [The introduction of overseas crops and the impact on China's agricultural production]. Gujin Nongye (Ancient and Modern Agriculture) 1 issue: 1-11.

Needham, Joseph. 1984. Science and Civilisation in China: Volume 6, Biology and Biological Technology, Part 2: Agriculture. Cambridge: Cambridge University Press.

Northrop, D. 2012. Introduction: the challenge of World History. In $A$ Companion to World History, ed. D. Northrop, 1-13. Oxford: Wiley-Blackwell. 
Ouyang, Chunlin. 2012. Fanqie de yinzhong yu Ming Qing Fujian yanhai shebui (1594-1911) [Introduction of Sweet Potato and Social Change in Fujian Coastal Communities in Ming and Qing Periods (1594-1911)]. Master's Thesis of Fujian Normal University.

Perkins, D.H. 1975. China's Modern Economy in Historical Perspective. Stanford: Stanford University Press.

Pomeranz, K. 2000. The Great Divergence: China, Europe, and the Making of the Modern World Economy. Princeton: Princeton University Press.

Qian, Chengdan. 2001. Probing into the Idea of 'Global History': An Impression of the 19th Congress of the International Historical Sciences. Shixue Yuekan (History Monthly) 2: 145-150.

Rawski, T.G. 1989. Economic Growth in Prewar China. Berkeley: University of California Press.

Song, Junling. 2007. Ming Qing shiqi meizhou nongzuowu zai zhongguo de chuanzhong ji qi yingxiang yanjiu [Studies on Spreading and Growing and Influences of Crops Originated in American During Ming and Qing Dynasties: Focusing on Maize, Sweet potato and Tobacco]. Doctoral Dissertation of Henan University.

Tu, W.M. 1998. Confucius and Confucianism. In Confucianism and the family, ed. W.H. Slote, and G.A. de Vos, 3-36. New York: State University of New York Press.

Von Glahn, R. 1996. Fountain of Fortune: Money and Monetary Policy in China, 1000-1700. Berkeley: University of California Press.

Von Glahn, R. 2016. The Economic History of China: From Antiquity to the Nineteenth Century. Cambridge: Cambridge University Press.

Vries, P. 2010. The California School and Beyond: How to Study the Great Divergence? History Compass 8 (7) (July): 730-751.

Waley-Cohen, J. 1993. China and Western Technology in the Late Eighteenth Century. The American Historical Review 98 (5) (Dec): 1525-1544.

Wang, Baoning. 2013. Qianlong nianjian Shandong de zaihuang yu fanshu yinzhong [Famine and the Introduction of Sweat Potatoes in Shandong in Qianlong Era]. Agricultural History of China (3): 9-26.

Wang Jiaqi. 1961. Lue tan gan he gan shu lu. [Slight Discussion about Sweet Potato and Record of Sweet Potato]. Cultural Relics 3: 27-30.

Wang, Shengpeng. 2015. Qingdai Sichuan meizhou liangshi zuowu de chuanzhong ji dui yinshi chansheng de yingxiang [The Introduction of American Crops in Sichuan in Qing Dynasty and Its Influence on Diet]. Journal of Sichuan Higher Institute of Cuisine (4): 6-9.

Wang, Yunlong. 2002. From Modernization to Globalization. Xuexiyu Tansuo [Study and Exploration] 3: 121-125.

Westad, O.A. 2012. Restless Empire: China and the World since 1750. Philadelphia, USA: Basic Books. 
Wong, R.B. 1997. China Transformed: Historical Change and the Limits of European Experience. Ithaca and London: Cornell University Press.

Wright, T. (ed.). 1992. The Chinese Economy in the Early Twentieth Century: Recent Chinese Studies. New York: St. Martin's Press.

Wu, Deduo. 1961. Guanyu ganshu he jinshu chuanxi lu [On the Sweet Potato and its Instruction]. Cultural Relics 8: 60-61.

Wu, Xiaoqun. 2005. Do We Really Need a 'Global View of History'? Xueshu Yanjiu (Academic Research) 1: 22-27.

Xia, Nai. 1961. Lüe tan fanshu he shuyu [Slight Discussion about the Sweet Potato and Dioscorea Opposita]. Cultural Relics (8): 58-59.

Xu, Dixin, and Chengming Wu (eds.). 1993. Xin Minzhuzhuyi Geming Shiqi de Zhongguo Zibenzhuyi [Development history of Chinese capitalism]. Beijing: People's Publishing House.

You, Xiuling. 2003. Qing chu yimin yu yimi ganshu zai Sichuan diqu de chuanbo [The Migrants in the early Qing Dynasty and the Distribution of Corns and Sweet Potato in Sichuan]. Agricultural History of China 22 (2): 6-22.

Yu, Pei. 2006. Global History and National Historical Memory. Shixuelilunyanjiu [Historiography Quarterly] 1: 18-30.

Zhang, Gang. 1955. The Research on the Yield of Crops in Qing Dynasty. Beijing: China Agriculture Press.

Zhang, Jian. 2001. Lun meizhou liang shi zuowu de chuanbo [On the spread of food crops in the Americas]. Zhongguo nong shi (Chinese Agricultural History) (3): 89-95.

Zhang, Jian. 2013. Nongzuowu chuanboshi yanjiu de lizuo: du meizhouzuowu zai zhongguo de chuanbo ji qi yingxiang yanjiu [A Masterpiece to Research the History of Crop's Spreading-Book Review on the Introduction of American-Originated Crops into China and their Long-Term Influence]. Agricultural History of China (2): 138-144.

Zhao Gang, Liu Yongcheng and Deng Bianzhu. 1995. Grain Yield per Mu of the Qing Dynasty. Jiangsu: China Agriculture Press.

Zheng, Nan. 2010. Meizhou yuanchan zuowu de chuanru ji qi dui zhongguo shehui yingxiang wenti de yanjiu [On the Introduction and Influence of American Native Crops on Chinese Society]. Doctoral Dissertation of Zhejiang University.

Zheng, Nan. 2013. Meizhou zuowu fanshu de chuanru ji zai Heilongjiang diqu de yinzhong yu zaipei [The Introduction of Sweet Potato and Its Cultivation in Heilongjiang]. Journal of Chuxiong Normal University 28 (8): 4-11.

Zhou, Yuanhe. 1983. Ganshu de tusheng, chuanru, chuanbo yu renkou [The Indigenous, Introduction and Distribution of Sweet Potato in Population]. Agricultural History of China 3: 75-88.

Zurndorfer, H. 1989. Change and Continuity in Chinese Local History: The Development of Hui-chou Prefecture, 800 to 1800. Leiden: Brill. 
Open Access This chapter is licensed under the terms of the Creative Commons Attribution 4.0 International License (http://creativecommons.org/licenses/ by $/ 4.0 /)$, which permits use, sharing, adaptation, distribution and reproduction in any medium or format, as long as you give appropriate credit to the original author(s) and the source, provide a link to the Creative Commons license and indicate if changes were made.

The images or other third party material in this chapter are included in the chapter's Creative Commons license, unless indicated otherwise in a credit line to the material. If material is not included in the chapter's Creative Commons license and your intended use is not permitted by statutory regulation or exceeds the permitted use, you will need to obtain permission directly from the copyright holder.

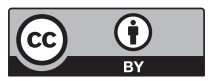

